\author{
Юрій Семенюк \\ аспірант кафедри глобалістики, європейської інтеграції \\ та управління національною безпекою ОРІДУ НАДУ при Президентові України
}

\title{
СТРАТЕГІЧНИЙ РОЗВИТОК ОСВІТИ В УМОВАХ ДЕЦЕНТРАЛІЗАЦІЇ (НА ПРИКЛАДІ БЕРЕЗІВСЬКОЇ ОТГ ОДЕСЬКОЇ ОБЛАСТІ)
}

\begin{abstract}
У статті аналізуються актуальні проблеми стратегічного розвитку освіти об'єднаних територіальних громад на прикладі Березівської ОТГ. Розглядаються вектори розвитку системи освіти територій, обгрунтовується актуальність розробки стратегї удосконалення системи освіти ОТГ, основні ї принципи. Надається методика розробки стратегії: діяльність експертної групи реформ ОTГ, творчих груп, аналіз зібраних даних на основі SWOTаналізу, вироблення бачення розвитку освіти в громаді, визначення набору стратегічних та операційних чілей, аналіз ризиків, моніторинг впровадження стратегії. Узагальнюється методика розробки та реалізації Освітньої стратегії Березівської ОТГ (мета, цілі, пріоритетні завдання, основні напрямки реалізації завдань, критерії оцінювання результативності реалізації Освітньої стратегіï).

Ключові слова: дещентралізація; стратегія розвитку освіти; об'єднана територіальна громада; методика розробка стратегї удосконалення системи освіти ОTГ; SWOT-аналіз; бачення розвитку освіти; ризики; моніторинг впровадження стратегіï.
\end{abstract}

Yuriy Semenyuk

PhD student, Global Studies, European integrationandnational security management Department, ORIPA NAPA under the President of Ukraine

\section{STRATEGIC DEVELOPMENT OF EDUCATION UNDER DECENTRALIZATION (THE CASE OF BEREZIVSKA AMALGEMATED LOCAL COMMUNITY OF ODESSA OBLAST)}

The objective of the paper is to analyze the actual problems of the education strategic development of the amalgamated local communities. The vectors for the development of the education system of territories are defined: $i$ ) compulsory vectors including the need to ensure the availability of education; ensuring the proper functioning of educational institutions etc; ii) additional vectors including opportunities for educational policy, that is, the policy-formation of the amalgamated local communities, the creation of their own education managerial bodies, the development of public-government partnerships in education, the provision of broad autonomy for educational institutions, the search of additional sources of financing, etc. The need to develop the Strategy for the Improvement of the Education System of the amalgamated local communities (Strategy) is determined by the need to harmonise territorial education with the new status and living conditions of the community in the context of the national educational reform, the purpose of which is to form a new dynamic model of the education system. The main principles of the functioning of such a model are: responsibility, sensitivity to the needs of the community, public administration, updated competence-oriented content of education, partnership pedagogy, learning in action, effective monitoring of the quality of education.

The methods for developing a strategy are described taking the case of Berezivs'ka amalgamated local community (ALC) of Odessa oblast. The activity of Expert Group on Reforms, of focus group discussions as well as the achievements of creative groups during the Strategic Session of Berezovs'ka ALC are described.

The methods include: the analysis of the collected data; SWOT-analysis; development of the vision of education in the community; identification of strategic and operational goals; risks; popularization of the strategy; monitoring of its implementation.

The purpose of the educational strategy, objectives of the Educational Strategy, priority aims of the Educational Strategy are described as well as the main directions of the implementation of the objectives of the educational strategy, the criteria for assessing the effectiveness of the implementation of the Educational Strategy, priority measures for implementation of the Educational Strategy and priority measures to ensure the implementation of the Educational Strategy.

It is concluded that decentralization in education is aimed at improving the learning process, increasing institutions' capacity and democratic participation of interest groups, and efficient distribution of resources. Decentralization creates new conditions for the activity of educational institutions, stimulates the creative activity of their residents and leadership, allows accumulating intellectual and technical support.

Key words: decentralization; strategy of education development; amalgamated local communities; methodology on developing a strategy for improving the education system of amalgamated local communities; SWOT analysis; vision of education development; risks; monitoring of strategy implementation. 
Постановка

проблеми
Ресрорма децентралізації започаткувала суттєві зміни в усіх складових суспільного життя. Разом із реформуванням територіальної організації влади відбуваються трансформації соціально-гуманітарної сфери, у тому числі - в освітній галузі. Перш за все, мова йде про якісні освітні послуги, фрормування оптимальної освітньої структури, створення ефективної системи управління закладами освіти, вдосконалення мотиваційних механізмів для суб'єктів освітнього процесу, а головне - фрінансування закладів освіти.

\begin{tabular}{c} 
Мета \\
\hline Аналіз \\
дстанніх \\
і публікеньій \\
Луговий, М. Пала \\
\hline Виділення \\
невирішених \\
раніше \\
частин \\
загальної \\
проблеми \\
\hline \\
\hline Виклад \\
\hline основного \\
матеріалу \\
\hline
\end{tabular}

Мета статті - аналіз актуальних проблем стратегічного розвитку освіти об'єднаних територіальних громад.

Проблемні питання освіти об'єднаних територіальних громад, впливу реформи децентралізації на освітню галузь досліджували В.Андрущенко, С. Буковинський, Л. Гриневич, Д. Дзвінчук, Г. Єльнікова, С. Крисюк, В. арчук, О. Шаблій та ін.

Однак ще недостатньою мірою проведено дослідження питань, пов'язаних із методикою розробки стратегій розвитку освіти новостворених територіальних об'єднань. Ця сорера діяльності місцевих рад $є$ вкрай актуальною і потребує ґрунтовного вивчення.

У широкому теоретичному плані питання децентралізації стосується надання суспільних послуг населенню, що у свою чергу вимагає вирішення питань розподілу повноважень, власності та фінансових ресурсів [1, с. 1]. Органи місцевого самоврядування, зокрема в ОТГ, на сьогодні мають можливість у контексті державної освітньої політики самостійно визначати та формувати основні вектори розвитку системи освіти на своїй території. Ці вектори можна розділити на два основних блоки [2, с. 107-108]:

1. обов'язкові - включають необхідність забезпечення доступності якісної початкової освіти за місцем проживання, зокрема у сільських поселеннях; забезпечення належного функціонування закладів освіти на своїй території для здобуття учнями якісної загальної середньої освіти незалежно від місця проживання;

2. додаткові - включають можливості для формування власної освітньої політики, тобто формування стратегії (плану) розвитку освіти на території ОТГ, створення власних органів управління освітою, створення опорних шкіл, розвиток громадсько-державного партнерства у сфері освіти, надання широкої автономії закладам освіти, пошук додаткових джерел фрінансування для реалізації освітніх проектів тощо.

Закон України «Про освіту» зазначає, що громада повністю відповідає на надання освітніх послуг на своїй території [3]. Ефективність надання послуг залежить від конкретної мети, якої намагається досягти рада громади. Стратегічний план розвитку освіти в громаді $€$ одним із основних документів, розробка якого акту- алізується відразу після створення адміністративних структур громади.

Актуальність розробки Стратегії удосконалення системи освіти об'єднаної територіальної громади (далі - Освітньої стратегії) обумовлюється необхідністю приведення територіальної освіти у відповідність із новим статусом та умовами життя громади в контексті державної освітньої рефоорми, метою якої $€$ формування нової динамічної моделі системи освіти. Основними принципами функціонування такої моделі є: відповідальність, чутливість до потреб громади, громадсько-державне управління, оновлений компетентнісно-орієнтований зміст освіти, наскрізний процес виховання, педагогіка партнерства, навчання в дії, ефективний моніторинг якості освіти. Важливими $€$ ретельне і об'єктивне вивчення міжнародного досвіду розвитку освіти, його зіставлення з вітчизняним та визначення шляхів запровадження в освітню практику кращих надбань.

Стратегія як документ стратегічного i, водночас, операційного характеру, потребує своєї методики розробки. Вибір методики опрацювання стратегії перш за все залежить від організаційного потенціалу громади $[4$, c. 7$]$.

Таким чином, документ Освітньої стратегії $є$ чітко структурованим, містить детальний перелік запланованих заходів. Рекомендована структура (зміст) стратегії розвитку освіти в ОТГ виглядає наступним чином [5].

1. Опис процесу та методології розробки документу стратегії. В цей розділ також включать список членів робочої групи та опис проведених зустрічей і інших етапів роботи над стратегією розвитку освіти ОТГ.

2. Діагностика існуючого стану системи надання освітніх послуг в громаді, в т.ч. - розроблена за підсумками діагностики матриця SWOT. В цьому ж розділі коротко описуються результати проведених соціологічних досліджень, опитувань і інтерв'ю з мешканцями, найбільш важливі виявлені потреби і проблеми. Розширений аналіз результатів досліджень, анкетувань або інша подібна інформація може бути включена в якості додатку до стратегії.

3. Висновки з процесу розробки плану оптимізації освітньої мережі.

4. Бачення, стратегічні і операційні цілі розвитку системи надання освітніх послуг в ОТГ. У цьому розділі коротко описується бачення, його структура та причини включення до нього тих чи інших аспектів. Також коротко описуються стратегічні і операційні цілі стратегії розвитку освіти. Основна частина цього розділу - детальний план заходів.

5. Опис системи управління впровадженням стратегії - процедура та періодичність проведення моніторингу і актуалізації, порядок роботи комітету з впровадження стратегії розвитку освіти і т. ін.

На сьогодні в Україні, з огляду на брак відповідного досвіду місцевих рад, процесом розроблення стратегії займаються переважно зовнішні експерти. У результаті, виявляються ризики, з якими стикаються органи місцевого самоврядування, зокрема голови громад, в організації процесу надання освітніх послуг. Така практика (залучення зовнішніх експертів до роботи над нетиповими і не рутинними завданнями.) $є$ типовою для малих органів місцевого врядування у Європі, які не можуть дозволити собі утримувати на постійній основі 
персонал зі специфічною кваліфрікацією. Великі громади, з потужними відділами освіти, мають достатньо кваліфікованого персоналу, щоб самостійно розробляти стратегію, залучаючи експертів до виконання специфічних завдань, як от проведення сесії зі SWOT-aналізу чи аналіз статистичних і фрінансових даних.

Процес розробки стратегії ми описуватимемо на основі досвіду Березівської ОТГ Одеської області. Відповідні пропозиції щодо удосконалення системи освіти в громаді були розроблені членами Експертної групи реформ Березівської ОТГ, утвореної розпорядженням Березівського міського голови від 07.12.2018 № 166/ МР-2018, на основі результатів фокус-групових дискусій з представниками освітян, батьків та активістів шкільного самоврядування, а також напрацювань творчих груп під час Стратегічної сесії Березівської ОТГ, проведеної у березні 2019 р.

Стратегічна сесія $€$ формою колективного вироблення та публічного обговорення представниками громади за участі експертів спільного бачення шляхів підвищення ефективності системи шкільної, дошкільної та позашкільної освіти громади, залучення школярів та молоді до участі у житті громади на основі поєднання зусиль органів публічної влади, підприємців та громадськості. У свою чергу, Стратегічна сесія проводилася на основі відповідної Методики підготовки і проведення стратегічної сесії Березівської міської об'єднаної територіальної громади у сфері шкільної, дошкільної та позашкільної освіти. Стратегічна сесія проводилася фрахівцями ВГО «Асоціація сприяння самоорганізації населення» (далі - Асоціації) в режимі динамічної мережі, що дало можливість поєднати експертні думки і пропозиції учасників у галузевому та міжгалузевому форматі. Учасниками Стратегічної сесії були: депутати міської ради профрільних постійних комісій; керівництво та фахівці (спеціалісти, методисти, голова профспілки працівників освіти, юристи) управління освіти, культури, сім'ї, молоді та спорту міської ради; адміністрація та педагоги шкіл та дошкільних закладів Березівської ОТГ; бізнесмени, що проживають або працюють в Березівській ОТГ; старости та інші представники сіл, що входять до складу Березівській ОТГ; представники батьківських комітетів шкіл та дошкільних закладів; старшокласники - представники шкільного самоврядування; представники громадських, релігійних, творчих, молодіжних, фрізкультурно-спортивних, культурно-виховних, науково-технічних організацій; представники IT-сфери (програмісти, веб-дизайнери), активні веб-користувачі, блогери; інші запрошені особи, які зацікавлені у розвитку Березівської ОТГ. Загальна кількість учасників Стратегічної сесії - 40 осіб. Для розгляду на Стратегічній сесії пропонувалися наступні питання, що були виявлені як пріоритетні на попередніх етапах в ході аналізу бюджетних витрат на освіту та у співбесідах із керівництвом Березівської ОТГ.

1. Покращення шкільної освіти.

2. Покращення дошкільної освіти і виховання.

3. Покращення позашкільної освіти і творчого розвитку дітей.

4. Залучення школярів та молоді до участі у житті громади.

5. Поєднання освіти та культурного життя у громаді.

У межах кожного напрямку окремо розглядалися питання співпраці органів управління, комунальних закладів з громадськістю, бізнес-структурами та донорськими організаціями для вирішення пріоритетних проблем Березівської ОТГ, а також різні фрорми співробітництва Березівської ОТГ із сусідніми громадами, районною радою, РДА, обласними структурами та іншими суб'єктами впливу на стан справ у громаді. Напередодні Стратегічної сесії по кожному із вказаних напрямків організатори заходу сформували 5 тематичних творчих груп (по 8 учасників, серед яких обов'язково були представники органів влади, підприємців і громадськості) та визначили їх координаторів. Кожна творча група отримала на сесії завдання для виконання - відповідно до тематичного профілю групи. У ході Стратегічної сесії кожна творча група під керівництвом модератора - самостійно та із залученням представників інших творчих груп - ретельно аналізувала існуючі проблеми та виробляла конкретні заходи, спрямовані на покращення стану справ і розвиток відповідної сфрери. Кінцевим продуктом діяльності кожної групи став план заходів з вирішення свого завдання на основі поєднання зусиль органів публічної влади, підприємців і громадськості. У межах плану заходів кожна творча група підготувала пропозиції щодо співробітництва Березівської ОТГ з іншими громадами Березівського району. На завершальній стадії Стратегічної сесії кожна група презентувала свої напрацювання усім іншим учасникам сесії. Під час публічної презентації інші учасники могли поставити запитання та надати свої пропозиції. На основі напрацьованих в ході Стратегічної сесії матеріалів експерти Асоціації разом із депутатами, фахівцями виконавчих органів Березівської міської ради та іншими членами Березівської громади та експертної групи реформ розробили План заходів 3 модернізації системи освіти у Березівській ОТГ, який після фрахової експертизи та публічного обговорення був затверджений міським головою (міською радою).

Для реалізації Плану з числа тих учасників, хто проявив найбільшу активність та результативність під час Стратегічної сесії, а також інших фрахівців, які проявили себе у відповідних сферах, керівництво Березівської ОТГ сфрормувало склад робочих груп за відповідними напрямками за участі представників місцевої влади, бізнесу і громадськості. Експертний супровід реалізації Плану заходів здійснювали відповідні члени Експертної групи реформ, створеної розпорядженням Березівського міського голови.

Задля формування місцевої Освітньої стратегії були зібрані дані в розрізі таких груп: матеріально-технічна база та обладнання, які належать школам, видатки шкіл у розрізі призначення (опалення, перевезення, заробітна плата вчителів і персоналу, ремонт, тощо), кількість учнів у кожній школі, інформація про кожну школу; дані про учителів та шкільний персонал кожної школи, дані про функціонування позашкільної освіти (кількість проведених занять, їх учасників, керівників, витрати), функціонування дошкільних навчальних закладів (кількість дошкільних груп, кількість дітей, кількість і кваліфікація вихователів, кількість і кваліфікація допоміжного персоналу, кількість і розмір приміщень). Аналіз зібраних даних проводився на основі SWOT-aналізу. У результаті цього вироблено бачення розвитку освіти в громаді, визначено набір стратегічних та операційних цілей, розглянуто обставини, які можуть перешкоджати впровадженню Освітньої стратегії. По- 
пуляризація стратегії передбачала і моніторинг її впровадження.

Згідно методики розробки стратегії було підготовлено Освітню стратегію громади. Мета Освітньої стратегії - розбудова в Березівській ОТГ системи якісної, конкурентоспроможної, доступної освіти відповідно до запитів особистості, вимог сталого інноваційного розвитку громади, суспільства, державних та європейських стандартів.

Цілі Освітньої стратегії: створення в Березівській ОТГ умов для розвитку доступної та якісної системи освіти, яка відповідає державним стандартам, актуальним і перспективним запитам особистості, громади і суспільства, сприяє всебічному розвитку людини як особистості, розвитку ії̈ інтелектуальних та фрізичних здібностей, вихованню суспільно активних та соціально відповідальних громадян; покращення матеріально-технічної бази та фінансового забезпечення закладів освіти Березівської ОТГ; забезпечення рівного доступу учнів, у тому числі учнів з особливими потребами до сучасної повноцінної, якісної освіти.

Пріоритетні завдання Освітньої стратегії зазначені нижче.

1. Забезпечити для усіх учасників освітнього процесу гарантії доступності та рівних можливостей отримання повноцінної освіти незалежно від місця проживання і матеріального статку, забезпечити прозоре фінансування сфери освіти.

2. Впроваджувати в освітній процес досягнення сучасної дошкільної, загальної середньої та позашкільної освіти із врахуванням схильностей, здібностей та особливостей кожного учня та вихованця.

3. Забезпечити здобуття освіти в умовах, що гарантують здоров'я, захист прав особистості вихованців, учнів в освітньому процесі, їх психологічну та фрізичну безпеку, реалізувати концепцію Нової української школи.

4. Запровадити систему управління освітою в ОТГ на основі співробітництва, консолідації фрінансових, кадрових та матеріальних ресурсів, активної співпраці усіх учасників освітнього процесу: учнів, педагогів, батьків, керівників навчально-виховних закладів.

5. Забезпечити умови для апробації та впровадження прогресивних технологій навчання, виховання, творчого розвитку, ефективних принципів організації освітнього процесу.

6. Підвищити професіоналізм, рівень матеріального стимулювання та соціальний статус педагогічних працівників.

7. Створити умови для більшої господарської і творчої самостійності закладів освіти.

Основні напрямки реалізації завдань Освітньої стратегії:

- покращення шкільної освіти;

- покращення дошкільної освіти і виховання;

- покращення позашкільної освіти і творчого розвитку дітей;

- залучення школярів та молоді до участі у житті громади;

- поєднання освіти та культурного життя у громаді.

У межах Освітньої стратегії реалізуються такі види забезпечувальних заходів: управлінське забезпечення; кадрове забезпечення; фрінансове забезпечення; матеріально-технічне забезпечення; нормативно-методичне забезпечення; інформаційне забезпечення.
Освітня стратегія реалізується шляхом:

- включення її основних завдань до складу цілей і завдань Стратегічного плану розвитку Березівської громади на 2019-2027 роки;

- розробки та ухвалення Березівською міською радою цільової Програми розвитку освіти у Березівській громаді;

- розробки та затвердження Березівською міською радою та ії̈ виконавчим комітетом окремих планів заходів з вирішення певних комплексів проблем в освіті (матеріально-технічного, кадрового, фрінансового забезпечення);

- врахування та виконання завдань Освітньої стратегії у поточній діяльності депутатських комісій, управління освіти та інших виконавчих органів Березівської міської ради через ухвалення організаційно-розпорядчих актів (наказів, планів-заходів, положень, посадових інструкцій та ін.);

- координації дій виконавців та контролю за ходом реалізації Освітньої стратегії силами Експертної групи ресоорм Березівської ОТГ.

- Критеріями оцінювання результативності реалізації Освітньої стратегії є:

- Оцінка рівня знань випускників шкіл Березівської ОТГ під час ЗНО.

- Відповідність рівня матеріально-технічного забезпечення та оснащення освітніх закладів державним вимогам та галузевим стандартам.

- Ступінь задоволення учнів та вихованців освітніх закладів якістю освіти та виховання.

- Ступінь задоволення батьків, діти яких відвідують освітні заклади, якістю освіти та виховання.

- Фінансові показники бюджетних витрат на одного учня (вихованця) освітнього закладу.

- Показники успішності участі учнів та вихованців освітніх закладів Березівської ОТГ у порівнянні з учнями та вихованцями освітніх закладів інших територіальних громад (конкурси, олімпіади брейн-ринги тощо).

- Спортивні і творчі досягнення учнів та вихованців освітніх закладів Березівської ОТГ у змаганнях, виставках, фестивалях та ін.

- Активність участі учнів, вихованців та їх батьків у суспільно-корисній діяльності на благо територіальної громади.

У Стратегії були визначені першочергові заходи за напрямками реалізації Освітньої стратегії та першочергові заходи із забезпечення реалізації Освітньої стратегії. Зокрема:

а) у сфрері управлінського забезпечення:

- оптимізувати структуру системи освіти Березівської ОТГ шляхом приведення її у відповідність із завданнями, ресурсними можливостями та перспективами розширення за рахунок приєднання нових територіальних громад;

- створити на базі Експертної групи реформ координаційну раду з розвитку освіти Березівської ОТГ за участі представників управління освіти, адміністрації навчальних закладів, батьків та старшокласників як спеціалізований постійно-діючий консультативно-дорадчий орган при міському голові;

- створити об'єднання батьків територіальної громади за участі представників батьківських 
комітетів усіх навчальних і виховних закладів Березівської ОТГ для координації дій у системі «педагоги-діти-батьки»;

- підвищити роль учнівського самоврядування, зосередивши його увагу, у тому числі, на стимулюванні учнів до спільної діяльності, спрямованої на покращення умов у школах, проводити семінари із успішними кейсами учнівської участі;

- запровадити систему кількісних та якісних показників оцінювання ефективності роботи освітніх закладів, засновану як на об'єктивному, так і на суб'єктивному їх оцінюванні (учнями, батьками, громадою);

- ввести у штатний розклад управління освіти спеціаліста з охорони праці;

б) у сфері кадрового забезпечення:

- розробити та затвердити заходи з розвитку кадрового забезпечення закладів освіти (шкільної, дошкільної та позашкільної) шляхом розробки та затвердження окремої місцевої цільової програми та включення до діючих місцевих цільових програм окремих напрямків, завдань та заходів, спрямованих на поліпшення кадрової спроможності закладів освіти Березівської ОТГ, зокрема:

- передбачити цільову підготовку місцевих молодих педагогів у ВНЗ з частковою оплатою вартості навчання за контрактом (з цивільною угодою про роботу в закладах освіти Березівської ОТГ після завершення навчання);

- передбачити перепідготовку та підвищення кваліфікації освітян у ліцензованих закладах післядипломної педагогічної освіти з частковою оплатою вартості навчання з місцевого бюджету;

- ввести стимулюючі виплати представникам освітньої галузі за рахунок коштів місцевого бюджету (надбавки, премії переможцям конкурсів);

- передбачити забезпечення молодих, перспективних педагогічних працівників власним та орендованим житлом за рахунок коштів місцевого бюджету;

- створити освітній резерв кадрів та цілеспрямовано працювати над підвищенням його професійного рівня, відродити наставництво;

- встановити премію вчителям за новітні розробки і впровадження нових навчальних технологій, багаторічні досягнення у підготовці учнів - переможців олімпіад, інтелектуальних змагань;

- передбачити міжшкільний трафік вчителів для забезпечення їхньої більшої мобільності та варіативності, налагодження особистих контактів між вчителями різних навчальних закладів, подолання "нездорової конкуренції" між цими закладами;

в) у сфері фінансового забезпечення:

- налагодити систему середньострокового та щорічного планування фінансового забезпечення закладів освіти;

- запровадити систему матеріального стимулювання керівників навчальних та виховних закладів освіти до інновацій та обґрунтовано економного витрачання бюджетних коштів;

- поступово переходити до використання методу планування фінансового забезпечення діяльності закладів освіти з урахуванням досягнутих результатів;
- залучати у сореру освіти позабюджетні кошти шляхом розроблення та реалізації проектів, які виконуватимуться за рахунок цільових фондів та зарубіжних донорських організацій;

г) у сфері матеріально-технічного забезпечення:

- надати освітнім закладам повноваження самостійно здобувати додаткове фрінансування, проводити тренінги з цього питання для освітян, забезпечити їх методичною допомогою;

- створити на базі кожного навчального та виховного закладу освіти об'єднання піклувальників за участі працівників, батьків, старшокласників та усіх бажаючих допомагати цьому закладу;

- створити у громаді благодійний фонд сприяння розвитку освіти;

д) у сфері нормативно-методичного забезпечення:

- у статуті територіальної громади прописати механізми участі учасників освітнього процесу у творчому супроводі та удосконаленні цього процесу;

- розробити модельний статут середньої школи та дошкільного виховного закладу для використання при отриманні цими закладами статусу самостійної комунальної установи;

- розробити модельний комплект організаційно-розпорядчих документів (положення про педагогічну раду, посадові інструкції певних категорій працівників закладів освіти) відповідно до вимог щодо роботи в нових умовах;

е) у сфері інформаційного забезпечення:

- регулярно висвітлювати на сайті громади, на сторінці «фейсбук» та у газеті Березівської ОТГ «Березівська правда» питання освітньої проблематики, кращий досвід, досягнення вчителів, учнів, діяльність батьківської спільноти та інші актуальні питання розвитку освітньої галузі;

- проводити тематичні навчальні семінари та дискусійні заходи для вироблення спільної позиції учасників освітнього процесу стосовно його удосконалення;

- популяризувати діяльність і досягнення Березівської ОТГ у сфрері освіти під час участі представників освітньої сфери громади в обласних, всеукраїнських та міжнародних конференціях, інших комунікаційних заходах.

Децентралізація в освіті спрямована на вдоско-

Висновки налення процесу навчання, підвищення спроможності закладів і демократичної участі груп інтересу, справедливого розподілу ресурсів. Децентралізація створює нові умови для діяльності закладів освіти, стимулює творчу активність їх колективів і керівництва, зближує школу з її середовищем, дає змогу акумулювати в ній інтелектуальну і матеріальну підтримку промисловців і всієї місцевої громади. У рамках політики, що формується на національному рівні, керівництво та управління освітою на місцевому рівні повинні бути здатними адекватно реагувати на потреби освітньої системи, аналізувати їх та визначати як стратегічні цілі.

\section{Література}

1. Бодак Н. В. Адміністративно-правові засади організації місцевої влади: сучасний стан та перспективи 
розвитку: автореф. дис... канд. юрид. наук. Ужгород. 2017. $18 \mathrm{c}$.

2. Децентралізація в Україні та її вплив на соціально-економічний розвиток територій: методичні підходи та результати оцінювання: наукова доповідь / наук. ред. д.е.н., проф. Сторонянської І.З. Львів: ІРД НАНУ, 2018. 144 c.

3. Про освіту Закон України від 09.08.2019 р. 2145VIII. URL: https://zakon.rada.gov.ua/laws/show/2145-19

4. Войцех Мархлєвскі, Олег Процак. Стратегія розвитку освіти в громаді: практичний порадник. Київ, 2018. 56 c.

5. Управління системою освіти територіальних громад: досвід країн Вишеградської четвірки для України: методичний посібник із збіркою кращих практик / А. Кавунець, А. Ланова, О. Гуменна, О. Черній, Р. Шарлея, Л. Грегуркова, Л. Одор, Л. Лакатош, Ш. Кьолеш, Е. Бураш. Вінниця: ТОВ «Твори», 2018. 120 с. 